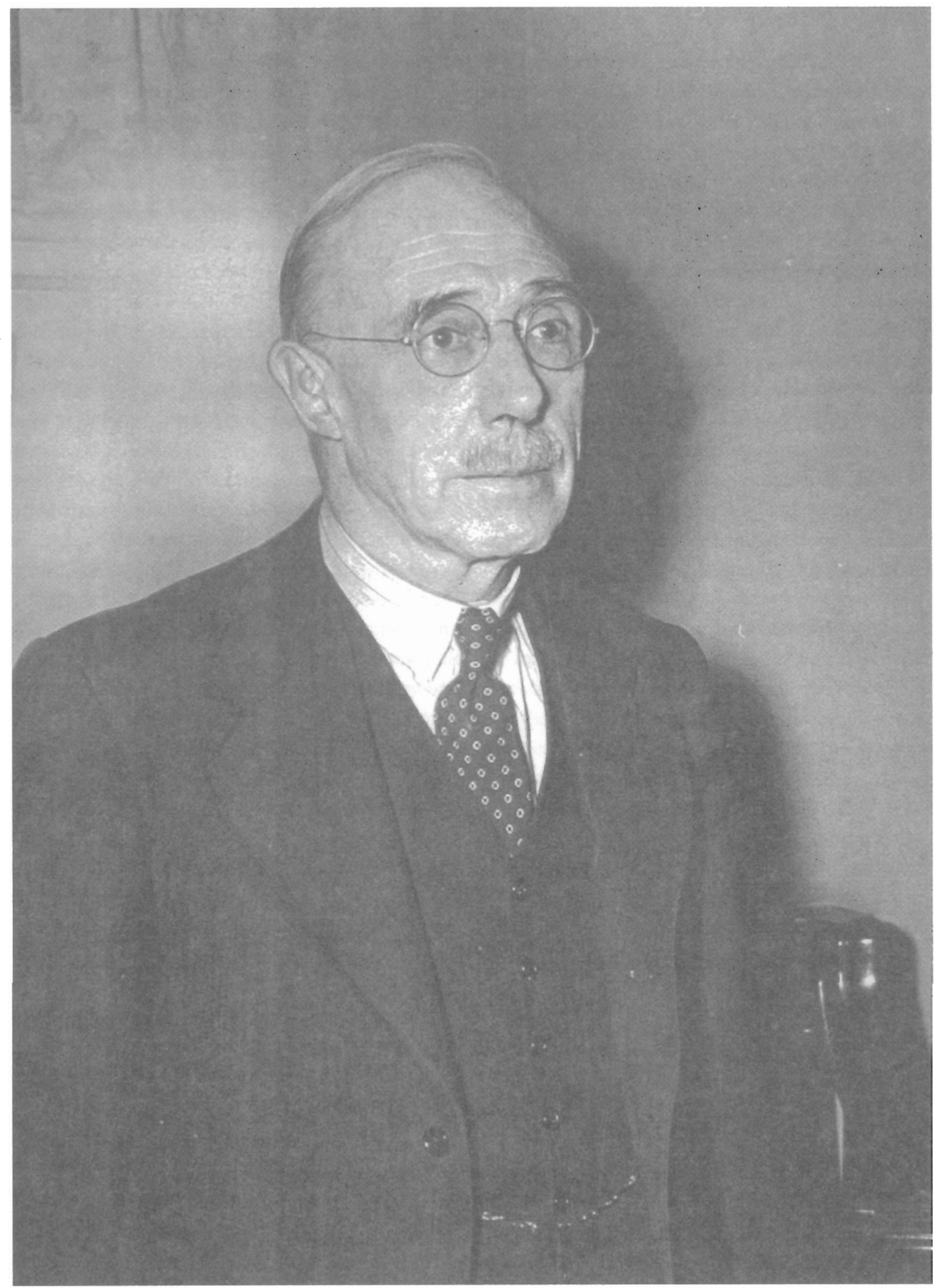

E. Godfrey Burr, circa 1950 (Photo copyright The Gazette, Montreal). 


\section{E. GODFREY BURR AND HIS CONTRIBUTIONS TO CANADIAN WARTIME RESEARCH: A PROFILE}

\section{By Marc Richard}

This paper sketches the life and work of Professor E. Godfrey Burr (1886-1969), of McGill's Department of Electrical Engineering, who Inade several little-known contributions to Canadian research and development during the First and Second World Wars. Most notably, Burr was the inventor of an imaginative method of concealing Allied surface ships from visual observation by enemy submarines during the Battle of the Atlantic. Although his camouflage technique was never used on a large scale, Burr's work illustrates the role played by numerous McGill scientists and engineers in the Allied R\&D effort during both World Wars.

Cet article brosse un tableau de la vie et du travail du professeur E. Godfrey Burr (1886-1969), du Département de génic électrique de l'Université Mc Gill, qui fit de nombreuses contributions peu conmues à la recherche et au développement au Canada durant la première et la deuxième guerre mondiale. Il inventa tout particulièrement une méthode imaginative d'empêcher la détection visuelle des navires de surface Alliés par les sous-marins ennemis au cours de la bataille de l'Atlantique. Bien que la technique de camouflage qu'il a élaboré n'a jamais été utilisé à grande échelle, le travail de Burr illustre le rôle qui fut joué dans l'effort de recherche et de développernent Allié au cours des deux guerres mondiales par de nombreux scientifiques et ingénieurs de McGill.

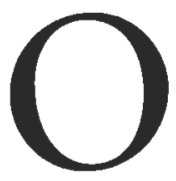

N AUGUST 14, 1945, the president of the National Research Council of Canada, C. J. Mackenzie, wrote to the Principal of McGill University, F. Cyril James, to express his appreciation for the work done at the NRC by a McGill professor during the past four years. Mackenzie's letter, which mistakenly identifies this individual as "Geoffrey" Burr, says in part:

As you know, Professor Bur is a man of great natural ability, is a most ingenious research worker and has a fertile innagination and practical knowledge. Professor Burr worked on a major project which received a very great deal of attention among Service Headquarters, and it does not detract in any sense from the very fine work he did that the development was not used tactically during this war. ${ }^{1}$
The work to which Mackenzie alludes so cryptically is a minor but intriguing footnote to the history of theSecond World War: the development of diffusedlighting ship camouflage, a system intended to help defend Allied convoys against night-time surface attacks by enemy U-boats. The experimental use that was made of this technique during the Battle of the Atlantic has received scant mention over the years, and its inventor - Professor E. Godfrey Burr, of McGill's Department of Electrical Engineering - likewise remains a little-known figure today. This paper offers a sketch of Burr's life and highlights the various defence-related research projects with which he was involved during both the First and the Second World Wars. 


\section{EARLY YEARS}

Edmund Godfrey Burr was born in the London borough of Islington on January 22, $1886 .{ }^{2}$ He was the youngest son of Herbert Greenwood Burr and Ellen Anne (Herbert) Burr, the fourth of five children who would be born to the couple. ${ }^{3}$ His father, a thirtynine year-old native Londoner, worked as a managing clerk for a coal exporting firm. His thirty-five yearold mother came from Bedworth, Warwickshire - a town located, coincidentally, near the future site of the Civil Defence Camouflage Establishment, at Leamington, to which Burr would travel in 1943 in connection with his diffused-lighting research. ${ }^{4,5}$

Burr's parents had moved to lslington not long before his birth, having previously lived in nearby Hornsey for over thirteen years. The family's new home, named Terlings, was situated on Orleans Road, which formerly conmected the still-extant Sunnyside and Cromartie Roads. Burr would live here up to 1906 , the year he moved to Montreal to study at McGill University. ${ }^{6}$

Burr received his early education at the nearby Tollington Park School. Unlike his two eldest brothers, who by their late teens were working as commercial clerks for colliery agents, Burr pursued his studies with a view towards a technical career.
In October 1903, at age seventeen, he enrolled in the Mechanical program at Finsbury Technical College, a school in central London operated by the City and Guilds of London Institute. ${ }^{7}$ The two-year program which Burr followed included courses in mathematics, mechanical drawing, geometry, practical chemistry, electrotechnics and machine design, as well as mechanical engineering laboratory work. ${ }^{8}$ Burr received a completion certificate in July 1905, then spent another year in the College's second-year Electrical program; he was awarded a certificate for this additional work in July 1906.

On the strength of this training, Burr was admitted directly into the fourth and final year of the Electrical Engineering program offered by McGill University's Faculty of Applied Sciences (as the Faculty of Engineering was called prior to 1931). ${ }^{9}$ During the 1906-1907 session, he studied electric lighting and power distribution, dynamo and machine design, mechanical engineering, alternating-current machinery, electrochemistry and hydraulics. He graduated in 1907, receiving a Bachelor of Science degree with honours in Electric Traction and in Electric Lighting and Power Distribution - subjects to which he would return in his subsequent research and consulting activities.

2 Edmund Godfrey Burr's registry of birth at the Office for National Statistics, General Register Office, Great Britain. Copy isssued to the author

3 Census of Population Returns for 1891, Administrative County of London, Civil Parish of St. Mary Islington, Orleans Road, Great Britain, Family Records Centre, RG12-146.

4 Guy Hartcup, Camouflage: A History of Concealment and Deception in War (New York: Charles Scribner's and Sons, 1980), 53.

5 "Inventions, Professor E. G. Burr," National Archives of Canada, RG24, Series D-13, vol. 11751, File CS 297-1.

6 "Finsbury Technical College Registers of Admissions of Day Students, with Analysis of Students' Backgrounds, 1902-03-1909. 10," Guildhall Library, London, MS 21,972 (2).

7 The building used by the College has survived intact and presently houses the Shoreditch County Court. The file on Finsbury Technical College is at the Finsbury Library, London.

8 "Finsbury Technical College Volumes Containing Lists of Day Students' Marks for Sessional Exams and Term Work, 1902-031910-11," Guildhall Library, London, MS 21,979 (3)

9 McGill University, Annual Calendar, 1907-1908. Appendix: "Pass Lists for Session 1906-1907".

10 University Staff Biographical Card File, McGill University Archives.

11 Victoria Daily Times, April 12, 1967, 38. 
Soon after graduation, Burr began to work as a demonstrator at the Department of Electrical Engineering. ${ }^{10}$ He was subsequently granted the position of Senior Demonstrator in 1909, and of Special Lecturer in 1911. In or about 1912, he married thirty year-old Grace Muriel Butler, a native Montrealer. ${ }^{11,12}$ The following year, he was appointed Lecturer in Electrical Engineering. Approval for his appointment to the rank of Assistant Professor, which he would hold for the next thirty years, was given by the Board of Governors on June 24, 1915. ${ }^{13}$

\section{WARTIME RESEARCH, 1914-1918}

Burr's initial interest in research appears to have been fostered by Professor Louis Anthyme Herdt, who served as Head of the Department of Electrical Engineering from 1909 until his death in 1926. The earliest scientific papers on which Burr worked, dealing with high-voltage transmission systems and with current-return systems for electric street railways, were both co-authored with Herdt, and were presented by the two men at meetings of the Canadian Society of Civil Engineers in 1915 and 1917. 14, I5 It was also through Herdt that, in those same years, Burr first became involved in secret wartime military research.
Upon the outbreak of the First World War in 1914 , Herdt had returned to his native France to offer his services to the authorities, despite the fact that he had been granted a permanent military exemption as a young man owing to his partial deafness. ${ }^{16} \mathrm{He}$ was instructed to go back to Canada, where he was soon put to work securing large orders for electrical cables and wires on behalf of the French Artillery Mission in New York. By 1915, Herdt had been appointed Honorary Technical Adviser to the Mission, and had recruited Burr to assist him with the requests for materials that he was now handling. ${ }^{17}$

Several of the inquiries sent to Herdt concerned a copper-cadmium alloy with unusual electrical and mechanical properties that was required for the manufacture of field-telephone cables. ${ }^{18,19}$ The alloy was unobtainable in North America and could not be produced in large quantities by any conventional process. Burr set to work on the problem of manufacturing this alloy with the help of a McGill lecturer in assaying and metallurgy, S. W. Werner; and apparently with some input from physicist Arthur S. Eve before the latter left for military service in Europe. ${ }^{20}$ Burr and Werner eventually developed a method whereby the exact proportions of cadmium required could be distilled into the copper at a controlled rate and without appreciable loss. This breakthrough

\footnotetext{
12 Copy of Grace Muriel Burr's death registration (issued to the author), Division of Vital Statistics, Province of British Columbia. 13 "McGill University, Governor's Minutes, 1897-1919," McGill University Archives, RG 4, C 7-8, Files 09007-09008, entries May 31, 1909, June 19, 1911, May 12, 1913, June 24, 1915.

14 Louis. A. Herdt and E. Godfrey Burr, "Constant voltage operation of a high voltage transmission system," Transactions of the Canadian Society of Civil Engineers 29 (1915): 234-63.

15 Louis. A. Herdt and E. Godfrey Burr, "Street railway negative return system for the mitigation of electrolysis," Transactions of the Canadian Society of Civil Engineers 31, pt. 1 (January-June 1917): 302-22.

16 Arthur S. Eve, "Louis Anthyme Herdt," Proceedings and Transactions of the Roval Society of Canada 3rd ser., 20 (May 1926): iii, xxi-xxiv.

17 McGill University, Annual Report, 1915-1916, (Montreal, McGill University, 1916), 38.

18 R. C. Fetherstonhaugh, McGill University At War, 1914-1918, 1939-1945 (Montreal: McGill University, 1947), 87-89.

19 Stanley Brice Frost, McGill University: For the Advancement of Learning, vol.2, 1895-1971 (Montreal: McGill-Queen's University Press, 1984), 105.

20 Eve, "Louis Anthyme Herdt," xxiii; Frost, McGill University, 104.
} 
allowed large-scale production of the alloy to be undertaken in secret in the United States, under Werner's direction, the total output being sufficient for the manufacture of several thousand miles of cable.

The procurement of the cable was considered a triumph of technical achievement by the French Mission, and in due course the government of France showed its appreciation to Herdt by investing him as Chevalier de la légion d'Honneur. The process developed by Burr and Werner was, in fact, regarded as so sensitive that the French government arranged to have patents for it withheld in Allied countries until after the end of hostilities in order to keep it out of enemy hands. This intervention caused the United States patent for the technique to be delayed until September 9, 1919, two years after it had first been approved by the U.S. Patent Office. ${ }^{21}$

\section{INTERWAR CONSULTATIONS AND AUDIOMETRY WORK}

After the Great War, Burr was able to turn his full attention to his teaching duties, to various research projects and to consultation work. The latter activity seems to have been concerned primarily with problems related to electric power plants. He had first acquired experience in this field in 1913-1915, when he had assisted Herdt in consulting for the development of the Bell Falls Hydroelectric Plant. ${ }^{22}$ In the late 1920s, Burr served as consulting engineer for the modernization of the Ottawa Electric Company's distribution system. ${ }^{2.3}$ Closer to home, Burr coauthored a report on the electric power supply situation at McGill University, which was submitted to Principal L. W. Douglas in June $1938 .^{24}$

In the late 1930s, Burr became involved in an audiometry research project which was to be of eventual service to the Canadian Army during the Second World War. The project, conducted jointly with Dr. Hector Mortimer, of the Montreal General Hospital, involved testing the loss of hearing ability in patients. Subjects were seated in a soundproof roon and were exposed to pure and warbling tones produced over a loudspeaker by a device which Burr had designed. This "open sound-field" technique was intended to yield more accurate results than audiometry tests which involved the use of earphones, since these could transmit unwanted vibrational stimulus to a subject's ears through direct conduction. ${ }^{25,26}$

The military application of this work was to come in the closing years of the Second World War, when Canada's armed forces began to pay increased attention to the serious auditory damage that could be caused by prolonged exposure to loud noises such as the sound of aircraft motors, ship engines and artillery fire. The Canadian Army in particular saw a need to test its soldiers for hearing loss at the time of their discharge in order to provide rehabilitative care to those who had suffered ear injury. Hector Mortimer, who was asked to develop suitable audiometric equipment and facilities, recommended the use of Burr's sound-generating device for conduct-

21 Fetherstonhaugh, McGill University at War, 88.

22 "Hydro-Electric Plant on Rouge River," Electrical News 24, no.13 (July 1, 1915): 24-27.

23 E. Godfrey Burr and S. A. Craig, "Complete installation of feeder reactors, Ottawa Electric Company," Electrical News and Engineering 38, no. 22 (November 15, 1929): 37-40.

24 "Electric Power Supply - Burr Report, 1938." McGill University Archives RG 2, C 53, File 705.

25 E. Godfrey Burr and Hector Mortimer, "Improvements in Audiometry at the Montreal General Hospital," Canodian Medicat Association lournal 40, no.1 (January 1939): 22-27.

26 E. Godfrey Burr, "Notes on the 'Warble Tone' Used in an Open Air Field Audiometer," Transactions of the Royal Society of Canada 3rd ser., 33, (May 1939): 73-81. 
ing these tests. Designated the "RCAMC (Royal Canadian Army Medical Corps) Audiometer," it became the standard instrument used at the Aural Rehabilitation Centre that was set up at the Montreal Military Hospital in $1946 .{ }^{27}$

\section{CAMOUFLAGE AND NIGHT-VISION RESEARCH, 1940-1945}

The most notable work which Burr undertook during the course of his career - the development of diffused-lighting (or "D/L") ship camouflage during the Second World War - was an unintended offshoot of a project assigned to him by the National Research Council in the fall of 1940. As part of an endeavour by the NRC to develop improved optical instruments for use by the armed services, ${ }^{28}$ Burr and Hector Mortimer had been studying the visibility range of aircraft viewed at night through large-aperture telescopes and binoculars. ${ }^{29}$ Burr found that aircraft observed with such instruments could be seen quite distinctly as black silhouettes against the faint background luminescence of the night sky. The observation suggested to him that a reduction of the brightness contrast between the aircraft and the sky could make a plane more difficult to see.

Burr witnessed a spontaneous demonstration of this principle on the night of December 4, 1940, when an aircraft he had been observing suddenly disappeared from sight while approaching to land at the airfield where he was conducting his research. Noting that the disappearance had occured when the plane had flown at low altitude over a snowcovered field, he realized that moonlight must have been reflected from the snow on to the underside of the fuselage; this diffused lighting had raised the brightness of the aircraft to the same level as that of the night sky, and the resulting lack of contrast had concealed the plane from observation.

Burr reported this discovery to the NRC, which promptly arranged for him to present his findings to Naval Service Headquarters in Ottawa. NSHQ recognized that diffused-lighting camouflage, if it could be applied to ships in a practical manner, might help defend Allied convoys against the tactic of nighttime surface attacks that German U-boats were successfully employing at that time. Because of their small size and low profile, U-boats operating on the surface at night could see merchant and escort vessels at significantly greater ranges than they themselves could be seen. D/L camouflage, it was hoped, could compensate for the visual detection disadvantage under which the convoys operated.

Beginning in early 1941, Burr was granted a series of leaves of absence from McGill which enabled him to spend most of the war working on $\mathrm{D} / \mathrm{L}$ camouflage at the NRC. ${ }^{30}$ During the course of the war, he had the opportunity to disclose his findings to American naval authorities, travel to Britain to assist the Admiralty in developing requirements for an improved D/L system, ${ }^{31}$ witness some of the full-scale $\mathrm{D} / \mathrm{L}$ trials that were conducted, and perform laboratory tests on the technique. ${ }^{32}$

\footnotetext{
27 National Research Council, Associate Committee on Army Medical Research, Medical Research and Development in the Canadian Army During World War II, 1942-1946 (Ottawa: National Research Council, 1946), 36-40.

28 File on large field telescope manufactured in Canada. Public Record Office, Creat Britain, ADM 1-15111.

29 E. Godfrey Burr, "Illumination for Concealment of Ships at Night," Transactions of the Royal Society of Canada 3rd ser., 41 (May 1947):45-54.

30 "McCill University, Covernor's Minutes, 1935-1944," McGill University Archives, RG 4, C 11, File 09014; entries !anuary 28, 1941, January 28, 1943, February 9, 1944, February 14, 1945.

31 Minutes of meeting on concealment by lighting held at the Admiralty, Whitehall, on August 25, 1943. Public Record Office, Great Britain, ADM 1-15214.

32 E. Godfrey Burr, "Illumination for Concealment of Ships at Night: Some Technical Considerations," Transactions of the Royal Society of Canada 3rd ser., 42, (May 1948): 19-35.
} 
A detailed analysis of the development work carried out on $\mathrm{D} / \mathrm{L}$ camouflage during the war is beyond the scope of the present paper. ${ }^{33}$ In broad outline, Burr's discovery led to an initial burst of experimentation by Canadian, British and American naval authorities, followed by a gradual decrease of interest as the war progressed. Although the D/L system was extremely effective in reducing the nighttime visibility range of the ships on which it was tested, it remained unsuitable for mass production and large-scale deployment. The prototype equipment took a great deal of time to develop, was cumbersome to install and operate, and was prone to breakdowns in the harsh environment of the North Atlantic. Even more fundamentally, improvements in Allied antisubmarine measures during the latter half of the war - notably the widespread use of centimetric radar and long-range patrol aircraft ultimately proved effective enough to render $\mathrm{D} / \mathrm{L}$ camouflage irrelevant to the protection of convoys. ${ }^{34}$

As an extension of his D/L work, Burr also spent time developing equipment and procedures for measuring the nighttime visual acuity of armed forces personnel. ${ }^{35}$ It was originally intended to administer such a test to new recruits in order to grade their night vision, so that their ability in this area could be taken into account when they were assigned tasks during active service. In practice, however, the test does not appear to have been widely applied: its systematic use would have been time-consuming, and the large number of grading procedures to which recruits were already subjected made it difficult to introduce additional criteria for allocating personnel.

\section{POSTWAR YEARS}

With the end of the war in Europe, the NRC terminated its work on D/L camouflage and Burr returned to his full-time duties at McGill. He was promoted to the rank of Associate Professor on June 13, 1945, one month before his special leave of absence to the NRC officially expired. ${ }^{36}$

It is not clear to what extent Burr's promotion was intended to recognize his wartime research, but more direct commendations were soon forthcoming. The congratulatory letter sent by NRC President C. J. Mackenzie to McGill Principal F. Cyril James has already been mentioned; it was followed, on July 1 , 1946 , by the announcement that Burr was to be made an Officer of the Civil Division of the Order of the British Empire. His OBE investiture by the Governor-General of Canada took place in Ottawa, on December 1, 1948, ${ }^{37}$ and was followed two months later by approval of his appointment to the rank of Professor of Electrical Engineering. ${ }^{38}$

Burr remained at McGill for two more years after his final promotion. On April 21, 1950, a few days after the McGill Senate approved the arrangements for his forthcoming retirement, Burr and six other long-serving academics were honoured at a reception at the McGill Faculty Club, of which Burr had served as President in $1940 .{ }^{39}$ The special guests that

33 The author is currently preparing a monograph on the subject. Fetherstonhaugh, McCill University at War, 337-341, and Burr, 1947 and 1948, for published summaries of the development of D/L camouflage. A description of D/L camouflage's use during a wartime special operation may be found in Michael L. Hadley, U-Boats Against Canada: German Submarines in Canadian Waters (Montreal: McGill-Queens University Press, 1985), 178-82.

34 Marc Richard, "Diffused-Lighting Ship Camouflage in the Battle of the Atlantic," Paper presented at the Fourteenth Naval History Symposium, United States Naval Academy, September 25, 1999.

35 Medical Research and Development, 5-12. (supra, note 27)

36 "McGill University, Governor's Minutes, 1945-1948," McGill University Achives, RG 4, C 12, File 09015, entry February 14, 1945.

37 Correspondence between Lt.-Col. Anthony Mather, Secretary of the Central Chancery of the Orders of Knighthood and the author. Letter dated September 19, 1997. 
evening included Professor William D. Woodhead, who was noted for writing humourous verse about his colleagues and who penned one such poem, "Ode to Godfrey Burr," on the occasion of Burr's birthday. ${ }^{40}$

Burr officially left McGill on his sixty-fifth birthday, January 22, 1951, though his actual departure took place on September 1,1950, owing to a leave of absence he was granted from that date onward. ${ }^{41}$ Soon thereafter, he and his wife Grace moved to Victoria, B.C., where they would spend their retirement. He died on April 12, 1969, at the age of 83, two years and one day after Grace's death on April $11,1967.42,43$

\section{CONCLUSION}

In their introduction to the recent book No Day Long Enough: Canadian Science in World War II, George R. Lindsey and G. LeRoy Nelms offer the following perspective on the vast number of research and development projects undertaken during the Second World War:

For every success achieved by Canadian scientists, there were many unfruitful tests and trails, promising leads that tumed out to be blind alleys, and even downright failures to find a practicable solution to some pressing wartime problem. This is the nature of research and development, especially when applied to fields in which there has been little previous experience.... But it is also true that, in the arcane world of research, each well-conducted test represents progress, whether or not it yields a solution to a problem. ${ }^{44}$

While it can be argued that Burr's work on diffusedlighting camouflage had less of a practical impact than the copper-cadmium alloying process he devised during the First World War, his experiments with the technique were nevertheless a positive and imaginative contribution to the Allied research effort during the Second World War - a conflict in which the scientific, technological and industrial capacities of the combatants played a decisive role. A fitting tribute to that contribution is to be found in the lext of Burr's OBE citation, ${ }^{45}$ which summarizes his work with the elegantly simple phrase:

"For outstanding service in connection with the development of highly specialized equipment for use by the Armed Forces."

The author wishes to express his appreciation to the staff of the following institutions for their assistance in researching this paper: the McGill University Libraries, the McGill University Archives, the National Archives of Canada, the National Library of Canada, the Directorate of History and Heritage of the Department of National Defence, the Public Record Office, the Family Records Centre, Guildhall Library and Finsbury Library. Special thanks are extended to Tomás, Pavlásek, Ellison Bishop, Margaret Hume and Alain Vaillancourt for their invaluable help and encouragement.

38 "McGill University, Governor's Minutes, 1948-1950," McGill University Archives, RG 4, C 13, File 09016, entry February 9, 1949.

39 Montreal Daily Star, April 22, 1950, 3.

40 Carman Miller, John Bland and Bruce Anderson, eds., A History of the McGill Faculty Club (Montreal: McGill-Queen's University Press, 1975), 44-45.

41 "McGill University, Governor's Minutes, 1948-1950," McGill University Archives, RG 4, C 13, File 09016, entry April 12, 1950.

42 Victoria Daily Times, April 16, 1969, 38.

43 Copy of Edmund Godfrey Burr's death registration (issued to the author), Division of Vital Statistics, British Columbia.

44 George L. Lindsey, ed. No Day Long Enough: Canadian Science in World War I/ (Toronto: Canadian Institute of Strategic Studies, 1997), 6 .

45 Correspondence between Mary de Bellefeuille-Percy, Director of Honours, Rideau Hall and the author. Letter dated October 1, 1997. 